\title{
The Interpretation of Anthropomorphic Verses in the View of Muhammad Husain Thabathabai
}

\author{
Nurul Khair', Siti Halimah ${ }^{2}$, Siti Hadaynayah Salsabila ${ }^{3}$ \\ ${ }^{1}$ Ahlul Bait International University, Tehran, Iran, \\ 2,3Sekolah Tinggi Filsafat Islam Sadra, Jakarta \\ nurulkhair97@gmail.com
}

\begin{abstract}
This writing is library research on Muhammad Husain Thabathabai's thought. It concerns about the anthropomorphist verses which is motivated by the interpretation of the Mujassimah to see that Allah SWT has a physical form in His existence by referring to anthropomorphic verses as the principle of argument. As a result, the existence of Allah as the Creator is the same as human existence. Besides the textual interpretation of anthropomorphic verses can be misunderstood, it's also known that rational view or liberal can cause misunderstanding in explaining about the meaning of divine word. In order to solve this problem, the writing is aimed to examine the interpretation of anthropomorphic verses to obtain the essence of existence of Allah SWT without relying on textual and rational understanding based on Muhammad Husain Thabathabai master piece, Al-Mīzan Tafsīr Al-Qur'an. By using descriptive-analytical method, this paper will get the conclusion that Muhammad Husain Thabathabai studied and examined the anthropomorphic verses using takwil approach as one of the esoteric interpretation methods which implies three terms, namely kinayah, siyaq or context of the verses, and Qur'an bil Qur'an. Based on these three terms, the authors use to question research that what are the implications of the interpretation of anthropomorphic verses in the view of the commentators and how Muhammad Husain Thabathabai's solution in solving the problematic interpretation of anthropomorphic verses. The results of this paper is to offer a new perspective in interpreting anthropomorphic verses, so that each individual can understand the essence and the degree of existence of Allah in his tawhid paradigm.
\end{abstract}

Keywords: Anthropomorphic Verses, Mujassimah, Interpretation, Takwil 


\section{Introduction}

Alquran is a revelation which revealed to Prophet Muhammad PBUH, and a living guidance that contains important values, such as ilm akhlaq, fiqh, and tawhid (oneness) for all human beings. ${ }^{1}$ In understanding those values, therefore we need a deeply discussion in accordance with the rules of Al Qur'an, especially the teaching of tawhid that need to be well understood. According to Yunan Yusuf, the teaching of tawhid in Islamic perspective taught about the oneness of God to present the view that God is spared from the anthropomorphist and mythology. ${ }^{2}$ This argument was supported with some verses of the Qur'an, which emphasize that Allah is One and nothing similar to Him, as in QS. Al-Ikhlas: 1-4, "Say: 'He, Allah, is One and invincible'. Allah-the Sustainer "needed by all'. He has never had offspring, nor was He born. And there is none comparable to Him." Whereas in QS. Asy-Syūra (42): 11, "He is ${ }^{\urcorner}$the Originator of the heavens and the earth. He has made for you spouses from among yourselves, and 'made' mates for cattle 'as well-multiplying you 'both'. There is nothing like Him, for He 'alone' is the All-Hearing, AllSeeing."

Based on the explanation of both Surah; QS. Al-Ikhlas and QS. AsySyūra, it can be known that Oneness of God is not similar to anything in His existence. Despite, there are some statement and arguments, which contrast to the verses above. One of the arguments who claim that they disagree with God's existence is not similar to everything was the mujassimah. A group which pioneered by Dawud al-Jawaribi said that "God are body, flesh and blood. He has parts of body, like two hands and two feet, head, tongue, two eyes, and two ears. Nevertheless, He is a different body compare to the others." 3 Whereas Abu Zahra explains that

1 QS:Al-Baqarah:2, Departemen Agama RI, Alquran dan Terjemahnya, (Bandung:J-ART, 2004), vol. 1, page. 2. See also; Jarman Arroisi, "Integrasi Tauhid dan Akhlak dalam Pandangan Fakhruddin Ar-Razi”. Jurnal Tsaqafah, vol. 9, number. 2, November 2013, page. 309

2 M. Yunan Yusuf, Alam Pikiran Islam Pemikiran Kalam: Dari Khawarij Ke Buya Hamka Hingga Hasan Hanafi, (Jakarta: Pranadamedia, 2014), page. 16

3 Al-Syahrastani, Al-Milal wa Al-Nihal: Aliran-Aliran Teologi dalam Islam,(Bandung:Mizan, 2004), page. 166 
God's existence in accordance with the existence of beings which has hand, eyes, foot and calves, as explained by al-Quran about His materials. ${ }^{4}$

Based on various view above, it can be understood that the thinkers at the beginning upholding the existence and all the attributes of God, but their failure in understanding the methodology of the interpretation of anthropomorphist verses literally had caused the similarity of existence and attributes of God are equals to beings (mujasssimah/musyabbihah)..$^{5}$ As a result, His existence and attributes has limitation, as well as the existence and attributes of being. To overcome the problem, other Muslim thinkers try to reconstruct the interpretation of the anthropomorphist verses by using different approaches, like takwil to gain transcendental meaning in each Divine word. One of the groups that study about the anthropomorphist verses is the Khalaf. The Khalaf argue that Quranic verse can be interpret (takwil) by certain sciences, such as letter wawu in the word warrāsikhūna in QS. Ali Imran (3): 7 as athaf letter, until appearing an understanding that the mutasyabihat verses was not only return to God, but someone within his knowledge (arrāsikhūna fi 'ilmi) can also interpret the mutasyabihat verses. ${ }^{6}$

Whereas an-Nawawi views, as been quoted by Ansori, in his work, Syarh Muslim said: "This is the true opinion, because impossible for God to call on his servants with something which aim was unknown to them."7 The anthropomorphic verses must be interpret with the use of language which in accordance with God's Greatness and perfection, like the interpretation of the word yadullah must be interpret into God's power, ma'akum was interpreted into togetherness in His knowledge and

${ }^{4}$ Ahmad Atabik, "Corak Tafsir Aqidah (Kajian Komparatif Penafsiran Ayat-Ayat Aqidah)”. Jurnal Esensia, vol. 17, number. 2, October 2016, page. 213

${ }^{5}$ Ahmad Atabik, "Corak Tafsir Aqidah (Kajian Komparatif Penafsiran Ayat-Ayat Aqidah)", page. 214

${ }^{6}$ Kerwanto, Metode Tafsir Esoeklektik, (Bandung:Mizan, 2018), page. 242

${ }^{7}$ Anshori, Ulumul Qur'an:Kaiah-Kaidah Memahami Firman Tuhan, (Jakarta: PT Raja Grafindo Persada, 2013), page. 139 
muraqab with the purpose to addresses the spiritual meaning which includes in a verse. ${ }^{8}$

Nonetheless, it needs to be known that the application of takwil as one method of interpretation also has various problem. Because, the method of takwil tend to keep away the textual and contextual value of Quranic verses, until the resulted meaning were contrast to the textual message. ${ }^{9}$ According to As-Suyuthi, the main criterion of interpretation is focus on Arabic spoken language. If one interpretation focused on Arabic spoken language, then it can be accepted. In contrast, if the interpretation is out from language corridor, then it abandoned. For the anthropomorphist verses are quite complicated, so that need to be discuss with a comprehensive and explanative perspective. ${ }^{10}$

By seeing many problems of interpretation to anthropomorphist verses, it needs solution as a form of concern toward various misunderstanding of Muslim thinkers toward the existence and attributes of God. This writing is trying to explain the takwil theory of Muhammad Husain Thabathabai, whose interpret God's anthropomorphist verses without leaving the Arabic spoken principles, as As-Suyuthi criteria. ${ }^{11}$ One of the takwil which was done by Thabathabai, is QS. Al-Fath (48): 10, "Surely those who pledge allegiance to you 'O Prophet' are actually pledging allegiance to Allah. Allah's Hand is over theirs(yadullah fauqa aydihim), Whoever breaks their pledge, it will only be to their own loss. And whoever fulfils their pledge to Allah, He will grant them a great reward."12

Thabathabai explain the word yadullah fauqa aydihim as literally means isti'arah khayaliyah and kinayah (parable), that is to swore and give promise to Rasulullah saw/the Prophet (PBUH) is the same as to

${ }^{8}$ Sansan Ziaul Haq, "Hermeneutika Sufistik: Telaah Epistemologi Takwil Ibn Arabi. Jurnal At-Tibyan, vol. 4, number. 1, July 2019, page. 2

${ }^{9}$ Hasan Yusufian, Kalam Jadid: Pendekatan Baru dalam Isu-Isu Agama (Jakarta: Sadra Press, 2014), page. 313

10 Mahmud Yunus, Tafsir Qur'an Karim, (Jakarta: Mahmud Yunus wa Dzurriyah, 2011), page. 758

${ }^{11}$ Muḥammad Husain Thabathabai, Al-Mīzan fì Tafsìr Al-Qur'ān, (Qom: Hauzah Alamiyah, 1417 M), vol. 18, page. 274

12 Departemen Agama RI, Alquran dan Terjemahannya, vol. 26, page. 512 
swear to God Almighty. People who swore to God Almighty who seek help from Him, as Thabathabai interpret the word yad in the sentence yadullah fauqa aidihim. ${ }^{13}$ Therefore, it can be known that the interpretation of QS. Al-Fath (48):10 according to the takwil of Muhammad Husain Thabathabai was not limit to textual meaning, as understood by the Mujassimah or rational method uses by the Muta'zilite in his takwil. On the contrary, Muhammad Husain Thabathabai uses two textual and takwil approaches with philosophical styles to achieve a true meaning in interpreting the anthropomorphist verses. ${ }^{14}$

Based on various explanations above, it can be known that the takwil method of Muhammad Husain Thabathabai involving textual and rational approach to discuss and study anthropomorphist verses which aimed to know the essence of God's existence in Divine words. This writing would like to explain the takwil of Muhammad Husain Thabathabai by using a descriptive-analytical qualitative method whose aimed to do research and study on the data or information about the anthropomorphist verses through primary and secondary sources. ${ }^{15}$

Primary source in this research is one of the magnum opus of Muhammad Husain Thabathabai by the title Al-Mĩzan fì Tafsìr al-Qur'ān. Whereas the secondary source in this research are books, journal, thesis and dissertation which discuses about the problem of the Anthropomorphist verses of God. ${ }^{16}$ The referenced data that based on primary and secondary sources was systematically describes by concerning of the writing rules of Ajis Journal. The described data will be deeply analyzed to gain a comprehensive and explanative discursive research for the sake of God's existence as the main purpose of this research.

13 Ikhlas Budiman, "Penerapan Teori-teori Filosofi dalam penafsiran al-Qur'an". Jurnal Tanzil, vol. 1, number. 1, 2015, page. 67. See also; Muhammad Husain Thabathabai, Al-Mīzan fì Tafsīr Al-Qur'ān, vol. 18, page. 275

14 Mohammad Ali, Memahami Riset (Jakarta: Pustaka Cendikia Utama, 2011), page. 239

15 Kaelan, Metode Penelitian Agama Kualitatif Interdisipliner (Yogjakarta: Paradigma, 2010), page. 143

16 Conny R. Semiawan, Metode Penelitian Kualitatif (Jakarta: PT. Grasindo, 2010), page. 10 
Based on various explanations above, this research is different with the previous researches, such as Ramli Awang and Roslan Abdul Rahim under the title "Anthropomorphism in Islamic Theology" was inputted in the Global Journal Al-Thaqafah that study about anthropomorphism concept in the approach of the hadith figure on God's attribute literally on the basis of argumentation of theologian and the ahlu Sunnah school of thought. ${ }^{17}$ Whereas this writing focusing on anthropomorphist verses in the view of the mufasir (interpreter) by showing takwil approach as one of interpretation method which less discuss in many researches.

What's more, the research done by Abdul Hamid Ritonga by the title of "Hadis-Hadis Antropomorfisme: Analisis terhadap Takwil Ibn Hajar Al-'Asqalani dalam Fath Al-Bari" on MIQOT: Journal of Islamic Studies which research and study on the problem of anthropomorphism in the hadith. The problem of anthropomorphism begins since there are debates among the hadith literalist with the Mu'tazilite which tend to be rational toward the verses that describing God attribute and human attribute. Through the research of kitab Fath al-Bari of Ibn Hajar, more focused on anthropomorphism discourse in the book of hadith by using takwil.18

Despite using takwil approaches, but the differentiation with this research is writer refer Al-Mĩzan fí Tafsìr al-Qur'ān, because the method of takwil in Muhammad Husain Thabathabai interpretation not forgetting the rational and textual approaches in philosophical styles, so that the takwil of Muhammad Husain Thabathabai showing the color of the anthropomorphist verses interpretation. Based on previous researches, it can be known that this research offering a new discourse by focusing on the interpretation of anthropomorphist verses discourses among the mufasir (interpreter). On the one side, this writing also offers a new view point in interpreting the anthropomorphic verses to know the essence of God's existence in the Quran. Based on the newness and difference of this

17 Ramli Awang dan Roslan Abdul-Rahim. "Antropomorfisme dalam Teologi Islam". Global Journal Al-Thaqafah, Issue. 2, vol. 7, December 2017, page. 135

18 Abdul Hamid Ritonga. "Hadis-Hadis Antropomorfisme: Analisis terhadap Takwil Ibn Hajar Al-'Asqalani Dalam Fath Al Bari”. Jurnal MIQOT, vol. XXXVII, number.2, July-December 2013, page. 240 
research from the previous discussion, writer hypothesizing that the takwil of Muhammad Husain Thabathabai can be solution for mistakes and failures of the interpretation of anthropomorphist verses done by Mujassimah and Mu'tazilite, and simultaneously disclosing the essence of God's existence in the interpretation of the anthropomorphist verses discourses as the main purpose of this research.

\section{Result and Discussion}

\section{Classification of the Anthropomorphic Verses in the Qur'an}

In Alquran there are anthropomorphic verses which identify that God has body (jism), it can be known and be found in some understanding word which uses wajhullah, yadullah, and ayn so that it present a tajassum and musyabbihah understanding in interpreting Quranic verses which implies to human beliefs toward God's existence. ${ }^{19}$ To make sure this research, writer will provide table to classify the verses that consider as anthropomorphic based on the word meaning in the Quran, so that reader can fully understand the meaning of the anthropomorphic verses as follows:

Table. 1 Classification of the Anthropomorphic Verses based on Tajassum and Musyabbihah

\begin{tabular}{|c|c|c|}
\hline No & Surah/Verse & Contain of the Verse \\
\hline 1 & $\begin{array}{c}\text { Al-Baqarah } \\
\text { [2]:115 }\end{array}$ & $\begin{array}{l}\text { To Allah belong the east and } \\
\text { the west, so wherever you turn } \\
\text { you are facing 'towards' } \\
\text { Allah. Surely Allah is All- } \\
\text { Encompassing, All-Knowing }\end{array}$ \\
\hline 2 & $\begin{array}{c}\text { Al-An'am } \\
{[6]: 52}\end{array}$ & $\begin{array}{l}\text { 'O Prophet!' Do not dismiss } \\
\text { those 'poor believers }{ }^{7} \text { who } \\
\text { invoke their Lord morning and } \\
\text { evening, seeking His }\end{array}$ \\
\hline
\end{tabular}

${ }^{19}$ Abdul Syukur, "Mengenal Corak Tafsir Al-Qur'an”, Jurnal El-FURQONIA, vol. 1, number. 1, August 2015, page. 97 
pleasure. You are not

accountable for them

whatsoever, nor are they

accountable for you. So do not

dismiss them, or you will be

one of the wrongdoers.

$3 \quad$ Al-Ra'd

And 'they are' those who

[13]:22

endure patiently, seeking their

Lord's pleasure, establish

prayer, donate from what We

have provided for them-

secretly and openly-and

respond to evil with good. It is

they who will have the

ultimate abode:

4 Al-Qașaș

And do not invoke any other

[28]:88

god with Allah. There is no god

'worthy of worship' except

Him. Everything is bound to

perish except He Himself.

5 Al-Rahman

Only your Lord Himself full of

[55]:27

Majesty and Honour, will

remain 'forever'

6 Ali Imrān

...all good is in Your Hands.

[3]:26 Surely You 'alone? are Most

Capable of everything.

$7 \quad$ Al- Hadid

'This is so' that the People of

[57]:29

the Book ' who deny the

Prophet ${ }^{7}$ may know that they

do not have any control over

Allah's grace, and that all

grace is in Allah's $\underline{\text { Hands. }}$

8

Al-Mulk Blessed is the One in Whose

[67]:1 Hands rests all authority. And 
He is Most Capable of everything

9 Hud [11]:37 And build the Ark under Our 'watchful' Eyes and directions, and do not plead with Me for those who have done wrong...

10 Al-Mu'minun So We inspired him: "Build the [23]:27 Ark under Our 'watchful ' Eyes and directions. Then when Our command comes and the oven bursts ${ }^{\top}$ with water ${ }^{\top}$

11 Al-Thur ...for you are truly under Our [52]:48 ' 'watchful ${ }^{1}$ Eyes...

12 Al-Qalam 'Beware of' the Day the Shin 'of [68]:42 Allah' will be bared, and the wicked will be asked to prostrate, but they will not be able to do so

13 Az-Zumar so that no ' sinful' soul will say [39]:56 'on Judgment Day', 'Woe to me for neglecting 'my duties towards ${ }^{7}$ Allah, while ridiculing 'the truth?'

14 Al-Baqarah $H e$ is the One Who created [2]:29 everything in the earth for you. Then He turned towards the heaven, forming it into seven heavens...

15 Al-A'raf Indeed your Lord is Allah Who (7):54 created the heavens and the earth in six Days, then established Himself on the Throne. 
16 Yunus [10]:3 Surely your Lord is Allah Who created the heavens and the earth in six Days, ${ }^{1}$ then established Himself on the Throne, conducting every affair.

17 Al-Ra'd [13]:2 It is Allah Who has raised the heavens without pillars-as you can see-then established Himself on the Throne. He has subjected the sun and the moon, each orbiting for an appointed term.

18 Țāha [20]:5 the Most Compassionate, 'Who is ${ }^{7}$ established on the Throne.

19 Al-Furqan 'He is' the One Who created [25]:59 the heavens and the earth and everything in between in six Days, then established Himself on the Throne. 'He is ${ }^{7}$ the Most Compassionate! Ask 'none other than' the AllKnowledgeable about Himself.

20 Al-Sajadah It is Allah Who has created the [32]:4 heavens and the earth and everything in between in six Days, then established Himself on the Throne. You have no protector or intercessor besides Him. Will you not then be mindful?

21 Al- Fussilat Then He turned towards the [41]:11 heaven when it was ${ }^{5}$ still like ${ }^{7}$ smoke, saying to it and to the earth, 'Submit, willingly or 
unwillingly.' They both responded, 'We submit willingly.'

22 Al-Hadid He is the One Who created the

[57]:4 heavens and the earth in six Days, ${ }^{1}$ then established Himself on the Throne. He knows whatever goes into the earth and whatever comes out of it,...

23 Al-Baqarah Are they waiting for Allah [2]:210 'Himself' to come to them in the shade of clouds,...

24 Al-An'am Are they awaiting the coming [6]:158 of the angels, or your Lord 'Himself', or some of your Lord's 'major' signs?...

25 Al-Qiyamah looking at their Lord. (75):23

26 Al-Fajr And your Lord comes 'to [89]:22 judge with angels, rank upon rank,

AlKahf [18]:28 And patiently stick with those who call upon their Lord morning and evening, seeking His pleasure.

28 Al-Lail but seeking the pleasure of [92]:20 their Lord, the Most High. sailing under Our ${ }^{r}$ watchful $^{\top}$ [54]:14 Eyes-a ' ${ }^{\top}$ fair ${ }^{\top}$ punishment on behalf of the one 'they' denied. He is the Only True God in the [6]:3 heavens and the earth... 
Based on table 1 it can be known that there are 30 anthropomorphist verses in the Quran. In searching of the anthropomorphist verses, writer uses thematically method in order to find word and theme related to the study in this research, which are anthropomorphist verses. The application of thematic method in interpretation has the urgency to focused on interpretation toward certain issue discusses, as this research uses thematic approach and focuses to dig and find anthropomorphist verses for 30 verses which includes in the Quran. ${ }^{20}$

Moreover, if it is classify through the tajassum and musyabbihah approaches, so it is known that the anthropomorphist verses are commonly called as tajassum, about 17 verses. Whereas, in the division of musyabbihah was 13 verses. The distinction of these two attributes can be found through some word meaning in the anthropomorphist verses, such as wajh (face), yad (hand), a'yun (eye), sāq (calves) which had mentioned many times in the Quran rather than the word istiwā (resides), and $j \bar{a}^{\prime} a$ or ityān (His arrival). ${ }^{21}$

Classifications of anthropomorphic verses as tajassum and musyabbihah also affirm by Rasyid Ridho and Aminullah El-Hady who view the word meaning of the anthropomorphic verses are mentioned as tajassum which indicate that the anthropomorphic verses discourse has viewing of God's existence physically. ${ }^{22}$ Even though, this writing will explains about the interpretation and method uses by the mufasir (interpreter) in understanding the anthropomorphic verses in tajassum and musyabbihah way in order to reach the meaning and the essence of God's existence from the two divisions through further discussion.

\footnotetext{
20 Ayu Fitri Lestari, Metode Pendidikan Islam (Kajian Tafsir Tematik). Essay (Lampung: State Islamic University Raden Intan, 2017), page. 35

${ }^{21}$ Al-Syahrastani, Al-Milal wa Al-Nihal: Aliran-Aliran Teologi dalam Islam, page. 166. See also; Ahmad Badrudin Firmanuloh, Metode Penafsiran Ayat-Ayat Mutasyabihat dan Implikasinya: Studi Komparasi Tafsir az-Zamakhsyari, ar-Razi, dan Ibn Taimiyah. Thesis, (Jakarta:IIQ, 2018), page. 8

${ }^{22}$ Aminullah El-Hady, Ibn Rusyd Membela Tuhan: Filsafat ketuhanan ibn Rusyd, (Surabaya: LPAM, 2004), page. 105
} 


\section{The Discourse of Interpretation of Anthropomorphic Verses}

The mufasir, such as Mahmud Yunus, Ibnu Katsir, Al-Zamakhshari, and Makarim Shirazi has different method of approach in interpreting and studying the anthropomorphist verses. ${ }^{23}$ The interpretation method of the mufasir can be traced through the books of tafsir in understanding the verses of Quran that contains the word wajh, istiwā, and yad. Author will explains about the interpretation of the interpreters (mufasir) about God's anthropomorphic verses based on three words above separately to gain a comprehensive and explanative discussion.

First discussion, which needs to be discussed, is interpretation of the word wajhullah: Qs. Al-Qașas [28]: 88. According to Muhammad Abdul Halim $^{24}$, in Arabic language, face, orientation and direction has the same root of word, which are (w-j-h): wajh (face), wijhah (direction), ittijäh, and jihah (orientation). Muhammad Abdul Halim strengthening his view by interpreting the word wajhullah in Qs. Al-Qașaș [28]:88 which means "to travel" and "to follow direction" that has harmonized meaning to the word liwajhillah in Arabic language which means to glorify the existence of God Almighty. 25

Based on the above meaning, some interpreters give response toward the meaning of wajhullah: Qs. Al-Qașaș [28]:88, according to Mahmud Yunus the word al-wajhuh is God's zat substance. Mahmud Yunus arguments also strengthen by Ibn Katsir who view that the sentence kullu shai'in hālikun illā wajhahu explains about God's existence will be eternal, so it's indicates that He is the Most Alive and stand-alone without any influence from other existence beside Him. ${ }^{26}$ The explanation of Mahmud Yunus and Ibn Katsir about the word al-wajhuh in accordance

${ }^{23}$ Saleh, Analisis Ayat-Ayat Mutasyabih Menurut Zamakhasyari dalam Tafsir AlKasysyaf. Essay, (Riau: State Islamic University Sultan Syarif Kasim, 2011), page. 4-5

${ }^{24}$ Abdul Halim, Muhammad. Memahami Al-Quran dengan Metode Menafsirkan Al-Quran dengan Al-Quran, (Bandung: Marja, 2012), page. 148

${ }^{25}$ Mahmud Yunus, Tafsir Qur'an Karim, page. 582

${ }^{26}$ Ibnu Katsir, Tafsir Ibnu Katsir, (Kairo: Imam Syafi'I Literature, 2011), vol. 1, page. 232 
with Al-Zamakhshari's view who interpret the word as God's substance. ${ }^{27}$ Meanwhile, the word Wajhuh in Qs. Al-Qașaș [28]:88 in Makarim Shirazi perspective understood as God's holy substance in spite of various limitations and destructions in His Being. It is different with human, animal and plants existences which will be devastated; because existentially, every being is coming from a substance or wajh. ${ }^{28}$

Second discussion, what needs to be answer is the interpretation of the interpreter about the word yad in Qs. Al-Fath [48]:10. Mahmud Yunus explain that the word yad is the hand of God who gives initiation to Muslim, so that every Muslim must follow His command and avoiding His prohibitions. If a Muslim doesn't obey His command, so he will get punishment. On the contrary, if a Muslim does every God's command, so, he will get reward. Interpretably, it is known that Mahmud Yunus give meaning to the word yad in Qs. Al-Fath [48]:10 textually by viewing that God has physical hand as human had. ${ }^{29}$

It is different with Ibn Katsir who interprets "Yadullāh fauqa aydihim" by the knowledge of God. Because, He is always with His servants to hear all their words, watching their every move, and knowing everything that is hidden. If someone doing a bad deed, then God will give punishment to them. On the contrary, He will give reward to those who does His Command. ${ }^{30}$ Ibn Katsir interpretation toward the word yad in Qs. Al-Fath [48]:10 was different with Al-Zamakhshari's view who say that "Yadullah fauqa Aydihim" was refer to the promise toward Prophets PBUH that has the same meaning to the promise toward God Almighty, so that every Muslim who promise to obey and follow Prophet PBUH means he promise to obey and following God. ${ }^{31}$

${ }^{27}$ Al-Qāsim Jārāllāh Maḥmūd bin 'Umar al-Zamakhsharī Al-Khawārizmī, Abī. AlKasyaf 'An Haqāiq Al-Tanzil Wa'uyūn Al-Aqāwil Fi Wujūh Al-Ta'wil, (T.tp: Dar al-Fikr, t.t), vol. 3, page. 437

${ }^{28}$ Naser Makarem Shirazi, Tafsir Al-Amthal Fī Tafsir Kitabillah Al-Manzil, (Qom: Madrasa Imam Ali bin Abi Thalib, $1461 \mathrm{H}$ ), vol. 12, page. 31

${ }^{29}$ Mahmud Yunus, Tafsir Qur'an Karim, page. 758

${ }^{30}$ Ibnu Katsir, Tafsir Ibnu Katsir, vol. 9, page. 39

${ }^{31}$ Muhammad Zammakhsyari, Al-Kasyaf 'An Haqaaiq Ghawamidh At-Tanzil, vol. 4 , page. 335 
Whereas, according to Makarim Shirazi the interpretation of yad in Qs. Al-Fath [48]:10 understood as Divine will and help which is greater than human beings. Shirazi exemplifies his views by interpreting "Yadullah fauqa Aydīhim" as a will that covers every deed and help which done by human, because $\mathrm{He}$ is above the existence of His beings. Therefore it can be known that Makarim Shirazi interpreting yad as God's help and power. ${ }^{32}$ It is different with Al-Zamakhshari who interprets yad as the word refers to a promise to the Prophet PBUH in accordance with a promise to God Almighty. Whereas, Ibn Katsir understanding yad as God's knowledge. Even though have different interpretation, three of them uses the same method in interpreting yad as in Qs. Al-Fath [48]:10 by not using textual approach. ${ }^{33}$ It is different with Mahmud Yunus who uses textual approach.

Third discussion that needs to be discussed related to the interpretation of the word istiwā (resides) as in Qs. Țaha [20]:5. Mahmud Yunus interpret istiwā which means resides. Textually, it is understood that Mahmud Yunus interpretation is describing of God Almighty, the Most Compassionate resides on the 'arsy or the Throne which always organize and command this whole wide universe. Even though understanding the istiwa textually, Mahmud Yunus was not intending to equalize God's to human who sat in the throne, as a King. According to Mahmud Yunus, it is impossible for God to organize the earth, sun and stars as a King who organized his people. Because, the existence of the sun which organized by Him who had the highest position compare to tiny and weak human being. ${ }^{34}$

Mahmud Yunus view is in accordance with Ibn Katsir interpretation which also interpret the word istiw $\bar{a}$ by means reside by quoting the view of the Salafian figure Salafus Salih, such as Imam Malik, Auza'i, ats-Tsauri, al-Laits bin Sa'ad, asy-Syafi'i, and Ishaq bin Rahawaih by letting the interpretation and understanding of the word istiwa as been page. 473

${ }^{32}$ Naser Makarem Shirazi, Tafsir Al Amtsal Fi Tafsir Kitabillah Al-Manzil, vol. 18,

33 Maliki, "Tafsir Ibn Katsir: Metode dan Bentuk Penafsirannya". Jurnal elUmdah: Ilmu Al-Qur'an dan Tafsir, vol. 1, number. 1, January-Juny 2018, page. 82-83

${ }^{34}$ Mahmud Yunus, Tafsir Qur'an Karim, page. 449 
interpret by the Salafis figure. ${ }^{35}$ It is different with Al-Zamakhshari interpretation who interprets istiwa as God's mastership sat on the throne of the kingdom, although His sitting is not like the king's sitting. ${ }^{36}$ Whereas, Makarim Shirazi interpretation about the word istiwa is not following any textual interpretation or following the Salafi figures. Moreover, Makarim Shirazi begin the interpretation of istiwā by paying attention on the meaning of 'arsy which understood as something above the sky. Sky (heaven) as the symbol of great and high power, so that الْعَرِِْ اسمَتَكَى is a form of kinayah of God's power which is so high and great. ${ }^{37}$

Based on various interpretations of anthropomorphic verses, it can be known that the mufasir has similarities and differences of interpretation. The similarities and differences of interpretation basically influenced by the method that uses, such interpretation of the word istiwa has the same meaning between Mahmud Yunus and Ibn Katsir, because both understand about the meaning of istiwā textually and also through the view of the salafi's figure.

Whereas other interpretation, which directed to different method by paying attention to the asbabun nuzul, textual understanding, and contextual value at that time, from the different method. To emphasize the interpretation of mufasir toward the anthropomorphic verses, author will provide table. 2 to make easier the understanding of the readers.

Table 2. The Difference of the Anthropomorphic Verses

\begin{tabular}{|c|c|c|c|c|c|}
\hline No & $\begin{array}{c}\text { Name of } \\
\text { Surah \& } \\
\text { Word }\end{array}$ & $\begin{array}{c}\text { Mahmud } \\
\text { Yunus }\end{array}$ & $\begin{array}{c}\text { Ibnu } \\
\text { Katsir }\end{array}$ & $\begin{array}{c}\text { Al- } \\
\text { Zamakhshari }\end{array}$ & $\begin{array}{c}\text { Makarem } \\
\text { Shirazi }\end{array}$ \\
\hline
\end{tabular}

35 Ibn Katsir, Tafsir Ibnu Katsir, vol. 3, page. 387. See also; Imam Al-Allamah Ibn Maznur, Lisan al-'Arab, (Mesir: Dar al-Hadits, 1423 H), page. 765

${ }^{36}$ Saleh, Analisis Ayat-Ayat Mutasyabih Menurut Zamakhsyari dalam Tafsir AlKasysyaf, page. 61

${ }^{37}$ Naser Makarem Shirazi, Tafsir Al Amtsal Fi Tafsir Kitabillah Al-Manzil, vol. 9, page. 527 


\begin{tabular}{|c|c|c|c|c|c|}
\hline & & $\begin{array}{c}\text { (Asy'arite } \\
\text { figure) }\end{array}$ & $\begin{array}{l}\text { (Asy'arite } \\
\text { figure) }\end{array}$ & $\begin{array}{l}\text { (Mu'tazilite } \\
\text { figure) }\end{array}$ & $\begin{array}{l}\text { (Syi'ite } \\
\text { figure) }\end{array}$ \\
\hline 1 & $\begin{array}{l}\text { Wajh: Qs. } \\
\text { Al-Qașaș } \\
\text { [28]:88 }\end{array}$ & Substance & Substance & Substance & $\begin{array}{l}\text { Substance } \\
\text { of } \\
\text { Muqadas }\end{array}$ \\
\hline 2 & $\begin{array}{l}\text { Yad: Qs. Al- } \\
\text { Fath } \\
{[48]: 10}\end{array}$ & Hand & $\begin{array}{l}\text { God's } \\
\text { knowledge }\end{array}$ & $\begin{array}{l}\text { Referring to } \\
\text { Prophet's } \\
\text { promises to } \\
\text { promise to } \\
\text { God }\end{array}$ & $\begin{array}{l}\text { God's } \\
\text { helps and } \\
\text { wills }\end{array}$ \\
\hline 3 & $\begin{array}{l}\text { Istiwā: Qs. } \\
\text { Țaha } \\
{[20]: 5}\end{array}$ & Resides & Resides & $\begin{array}{l}\text { Control over } \\
\text { a kingdom }\end{array}$ & $\begin{array}{l}\text { Great } \\
\text { Power }\end{array}$ \\
\hline
\end{tabular}

From various explanation and simplification gained from table.2, it can be known that the interpretation of the anthropomorphic verses which done by the mufasir as kinayah or parable. Because, the interpreter (mufasir) viewing the word yad, istiwa a, and wajh in Alquran which meaning must be clear as a form of parable. But, the interpretation resulted was subjective without involving the approach of siyaq and Qur'an bil Qur'an to gained textual meaning as objective and inner. As a result the interpretation that discusses and research by the mufasir, whether classic or contemporary has not given any comprehensive explanation. To solve the problem of interpretation, needed a solution as a form of attention toward the discourse of the interpretation of anthropomorphic verses which involves three approaches, kinayah, siyaq, and Qur'an bil Qur'an. One of the mufasir who discuss the anthropomorphic verses through three approaches is Muhammad Husain Thabathabai.

Muhammad Husain Thabathabai explains three approaches in one of his masterpieces by the tittle Al-Mīzan fí Tafsīr al-Qur'ān. According to Ilyas Husti, Al-Mìzan fì Tafsìr al-Qur'ān is a work that interprets the verses of Alquran in detail from many aspects, so that it shows a 
comprehensive and explanative side. ${ }^{38}$ Whereas in the view of Tâalal Hasan quoted by Kerwanto, one of the activists of Thabathabai's thought, explains that Al-Mizan fi Tafsìr al-Qur'än is a work that explains about the esoteric values of Qur'anic verses without ignoring its textual value.39 Based on various view, it can be fully understood that the takwil of Muhammad Husain Thabathabai interpreting the anthropomorphic verses universally, covering text and ratio without ignoring one another. To exemplify this view, author will explain about the takwil of Muhammad Husain Thabathbai in further explanation.

\section{The Interpretation of Anthropomorphic Verse in the Takwil of Muhammad Husain Thabathabai}

In Al-Mìzan fì Tafsìr al-Qur'ān, it is known that Muhammad Husain Thabathabai uses two approaches to interpreting anthropomorphic verses, that is the method metode tahlili and esoteric. ${ }^{40}$ The tahlili method in the Muhammad Husain Thabathabai interpretation is functioned to explain about the contained meanings in Quranic verses by paying attention on the vocabularies, linguistic explanation, whether from the i'rab, balagah, and messages contained in it. ${ }^{41}$ The result of the tahlili method will be analyze by esoteric method or takwil to achieve an inner meaning of the anthropomorphic verses, so that it can be understood that the textual meaning in Muhammad Husain Thabathabai interpretation has an important position to deliver al-Qur'an scholars to know the inner

38 Ilyas Husti, "Studi Kritis Pemikiran Quraish Shihab Terhadap Tafsir Muḥammad Husain Țabāțabā'i”. Jurnal Al-Fikra, vol. 14, number. 1, January-July 2015, page. 65

39 Kerwanto, "Penafsiran Bāthini (Esoteris) Thabāthabā'i dalam Tafsir alMīzān". Jurnal Tanzil, vol. 1, number. 2, 2016, page.190

${ }^{40}$ Islah Gusmian, Khazanah Tafsir Indonesia:Dari Hermeneutik Hingga Ideologi, (Jakarta:Teraju, 2013), page. 196. See also; Fiddian Khairudin, "Makna Imam Menurut Al-Thabathaba'i dalam Kitab Al-Mizan fi Tafsir Al-Qur'an". Jurnal Syahadah, vol. 5, number. 1, April 2016, page. 7

41 Kerwanto, "Penafsiran Bāthini (Esoteris) Thabāthabā'i dalam Tafsir alMīzān", page.190. See also; Yusno Abdullah Otta, "Dimensi-Dimensi Mistik Tafsir AlMizan: Studi atas Pemikiran Thabathaba'i dalam Tafsir Al-Mizan". Jurnal Potret Pemikiran, vol. 19, number. 2 (2015), page. 79 
meaning included in the divine word through a deep explanations of takwil. ${ }^{42}$

Based on the tahlili and esoteric approaches, it is known that Muhammad Husain Thabathabai divided the result of his interpretation toward the Anthropomorphic verses into three parts, among others, kinayah, siyaq, and Qur'an bil Qur'an in order to shows a comprehensive and explanative discussions, and to solve the lack of interpretation of the mufasir that only explains the anthropomorphic verses by kinayah. To emphasize those explanations, author will explain about the interpretation of the anthropomorphic verses according to the takwil of Muhammad Husain Thabathabai based on the word Wajh, Yad, Janbullah, and Istiwa which explains separately.

a. On the Word Wajhullah (Face) in Qs. Al-Qașaș [28]: 88

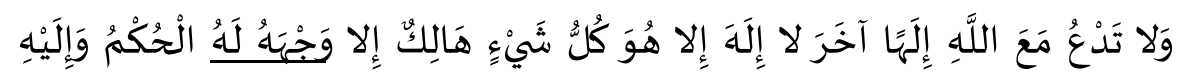

تُرْجَعُونَ

And do not invoke any other god with Allah. There is no god 'worthy of worship ${ }^{7}$ except Him. Everything is bound to perish except He Himself.

Thabathabai explain the word al-wajhuh in Qs. Al-Qașaș [28]:88 means that something which has the attributes of the Almighty. Something that has the Almighty attribute describing His existence as awaken from all destruction which is different with another existence, such as human beings, animals, and plants which surely will experience destruction. Based on Thabathabai's understanding, it is known that Qs. Al-Qașas [28]:88 as kinayah explain about the different substance of God and being. Thabathabai strengthen the understanding of kinayah by discussing the sentence of "Kullu syai"in halikun illa wajhu" in Qs. Al-Qașaș [28]:88.43

42 Ikhlas Budiman, "Penerapan Teori-teori Filosofi dalam penafsiran al-Qur'an”, page. 67. See also; Ahmad Fauzan, "Manhaj Tafsir al-Mizan fi Tafsir al-Qur'an Karya Muhammad Husain Tabataba'i". Jurnal Ilmu Alquran dan Tafsir: Al-Tadabbur, vol. 3, number. 2, Oktober 2018, page. 118

${ }^{43}$ Muhammad Husain Thabathabai, Al-Mìzan Fī Tafsīr Al-Qur"an, vol. 16, page. 97 
According to Thabathabai, the word هَلِّن in a sentence "Kullu syai "in halikun illa wajhu" as a predicate was mean death or nothingness. After explaining the word halikun, Thabathabai interpret the word kullu syai'in that become isim fa'il describing future time, which means everything will experience death or nothingness in its existences, except for His face (existence). ${ }^{44}$ The word "illa wajhu" explains about substance or God's existence which is different with beings that experience destruction, whereas God is free from any destruction. Because, existentially, $\mathrm{He}$ has the Living attributes through His existence everything's becomes alive. ${ }^{45}$ On the contrary, God doesn't need anything to make Him alive. Therefore, it can be known that the word al-wajhuh in Qs. Al-Qașaș [28]:88 explain about God's existence regardless of many weaknesses, especially destruction. It is different with the existences outside His existence which has many shortages and weaknesses so that human must realize that nothing need to be worship beside Him.

b. On the word Istiwā' (reside) in Qs. Tāha [20]:5

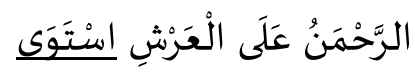

"the Most Compassionate, 'Who is ' established on the Throne."

Thabathabai explain the word istiwā means tauhid rububiyyah (the All Encompasses Everything). The word istiwa also mention that in verse 4, the explanation about this istiwā'alā al-'arsy has been explained many times in Qs. Al-A'raf: 54, Qs. Yunus: 3, Qs. Al-Sajdah: 4, and Qs. Al-Hadid: 4. It is different with Mahmud Yunus and Ibnu Katsir who interprets the word istiwa that God the Most Compassion has resides on the throne ('arsy) without explaining about kinayah. According to Thabathabai the language (lughawi) meaning of the sentence istiwā' alä al-'arsy means kingdom. Thabathabai explanation is in accordance with Makarim Shirazi

${ }^{44}$ Ahmad Fauzan, "Manhaj Tafsir al-Mizan fi Tafsir al-Qur'an Karya Muhammad Husain Tabataba'i". Jurnal Ilmu Alquran dan Tafsir: Al-Tadabbur, vol. 3, number. 2, Oktober 2018, page. 118

45 Muhammad Husain Thabathabai, Al-Mīzan Fī Tafsīr Al-Qur"an, vol. 16, page. 97 
and Al-Zamakhshari who also understand it as God's kingdom and His Power. ${ }^{46}$

But it needs to be known that on the siyaq approach, Muhammad Husain Thabathabai was not in accordance with al-Zamakhshari who understood the sentence of istiwa 'ala al-'arsy was like God sat on the throne, but he explains that the meaning of istiwā'ala al-'arsy describing the existence of God as the ruling master, to take care of, maintaining, and controlling everything in the universe. Muhammad Husain Thabathabai emphasizing his view by quoting 4 verses, that has been mentioned above, which explains about His Greatness, His Power and His Holiness as the existence of the Almighty related to tauhìd rububiyyah. ${ }^{47}$ Therefore it can be known that God Almighty is the Absolute authority over the universe. He takes care of, ordained, and controlled everything under His Greatness and Holiness. It is of course, all these things regardless of human existence that has limitation and weaknesses in his existence.

c. On the word Yad (Hand) in Qs. Al-Fath [48]:10

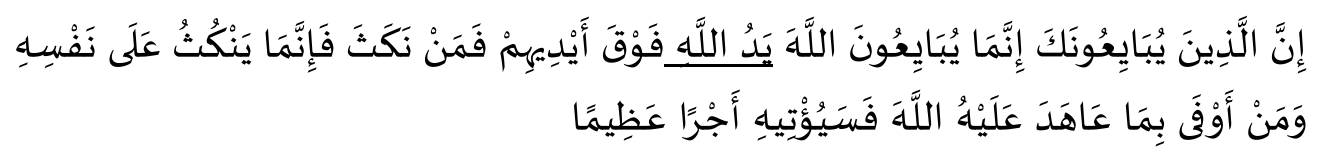

"Surely those who pledge allegiance to you 'O Prophet' are actually pledging allegiance to Allah. Allah's Hand is over theirs. Whoever breaks their pledge, it will only be to their own loss. And whoever fulfils their pledge to Allah, He will grant them a great reward."

Muhammad Husain Thabathabai interpret "Yadullāh fauqa aydīhim" in Qs. Al-Fath [48]:10 as figurative form which showing reference of the Prophet to God Almighty which harmonize with Qs. AnNisa [4]: 80, which says; "Surely those who pledge allegiance to you 'O Prophet ${ }^{7}$ are actually pledging allegiance to Allah." 48 the interpretation of 4, Hal. 335

${ }^{46}$ Muhammad Zammakhsyari, Al-Kasyaf'An Haqaaiq Ghawamidh At-Tanziil, vol.

${ }^{47}$ Mahmud yunus, Tafsir Qur'an Karim, hal.449. See also; Ibn Katsir, Tafsir Ibnu Katsir, vol. 3, page. 387. See also; Imam Al-Allamah Ibn Maznur, Lisan al-'Arab, hal. 765. See also; Naser Makarem Shirazi, Tafsir Al Amtsal Fi Tafsir Kitabillah Al-Manzil, vol. 9, page. 527

${ }^{48}$ Muhammad Husain Thabathabai, Al-Mizan Fī Tafsīr Al-Qur'an, vol. 18, page. 
Muhammad Husain Thabathabai correspond to Al-Zamakhsyari who also view the sentence "Yadullāh fauqa aydīhim" as making a promise to the Prophet PBUH means making promise to God Almighty. ${ }^{49}$ It is different with Muhammad Yunus interpretation which explains the sentence "Yadullāh fauqa aydīhim" as His Hand is over the hand of being, which describe that God Almighty has hand as human does. ${ }^{50}$ As a result, God's existence understood as material being. Whereas, Ibnu Katsir interpret the sentence of "Yadullāh fauqa aydīhim" with meaning His Knowledge that exist within them and He listen all their sayings, see them, and knowing what they hid inside their heart. 51

Based on various explanations above, it can be understood that Muhammad Husain Thabathabai interpret the sentence of "Yadullāh fauqa aydìhim" by kinayah to know and understand the meaning of yad, means refer to Rasulullah saw. It is different with the interpretation of Ibnu Katsir by understanding the word yad as His knowledge and Mahmud Yunus who view word yad as hand, as mention in Qs. Al-Fath [48]:10. Besides interpreting as kinayah, Muhammad Husain Thabathabai also explain through the esoteric approach that sentence "Yadullāh fauqa aydihim" means as His power and help encompasses everything beyond being. His help and power encompasses everything as a pleasure, guidance, and gift given by God Almighty to all human being and all other creatures, so that they need to make a vow for all the good that God has given in His Will. ${ }^{52}$

This esoteric interpretation is in accordance with the view of Makarim Shirazi who view the sentence "Yadullāh fauqa aydīhim" as His help and Will. But it also has differentiation that Muhammad Husain

${ }^{49}$ Muhammad Zammakhsyari, Al-Kasyaf 'An Haqaaiq Ghawamidh At-Tanziil, vol. 4, page. 335

${ }^{50}$ Mahmud Yunus, Tafsir Qur'an Karim, page. 758. See also; Ibnu Katsir, Tafsir Ibnu Katsir, vol. 9, page. 39

51 Siti Khasinah, "Hakikat Manusia Menurut Pandangan Islam dan Barat". Jurnal Ilmiah Didaktika, vol. 13, number. 2, Februari (2013), page. 312. See also; Supriadi, " AlAsy'ariyah (Sejarah, Abu al-Hasan al-Asy'ari, dan Doktrin-DoktrinTeologinya)". Jurnal Sulesana, vol. 9,number. 2, 2014, page. 69

52 Muhammad Husain Thabathabai, Al-Mizan fii Tafsir Al-Qur'an, vol. 18, page. 275 
Thabathabai understood the sentence "Yadullāh fauqa aydīhim" in detail, as His gift, guidance and enjoyment. ${ }^{53}$ Therefore, it can be understood that the word yad as a form of kinayah which means referring of the Prophet PBUH toward God Almighty. The meaning of kinayah emphasize by Muhammad Husain Thabathabai through the approach of Qur'an bil Qur'an that has harmonization with Qs. An-Nisa [4]:80 which means obeying the Prophet PBUH means obeying God Almighty. Whereas in esoteric approach, Muhammad Husain Thabathabai understanding the word yad as His help and power which comprises everything, so it can be known that these representations (takwil) and interpretations can free up His existence from many arguments that always describing God's existence like human that has physical form with various shortage and weaknesses in His existence. To emphasize the variety of representations and interpretations of Muhammad Husain Thabathabai toward anthropomorphic verses, therefore, writer provide table 3 as description of the whole image of subtheme.

Table 3 The Interpretation of Anthropomorphic Verses in the Takwil of Muhammad Husain Thabathabai

\begin{tabular}{|c|c|c|c|c|c|}
\hline No & Shighah & Verse & Kinayah & Siyaq & $\begin{array}{c}\text { Qur'an bil } \\
\text { Qur'an }\end{array}$ \\
\hline 1 & وَجْهَهُهُ & $\begin{array}{l}\text { Qs. Al- } \\
\text { Qașaṣ } \\
\text { [28]:88 }\end{array}$ & Essence & $\begin{array}{l}\text { Thabathabai } \\
\text { explains that } \\
\text { the } \\
\text { interpretation } \\
\text { of the verse } \\
\text { "Kullu syai"in } \\
\text { halikun illa } \\
\text { wajhu" means } \\
\text { that God's } \\
\text { holy } \\
\text { substance }\end{array}$ & $\begin{array}{l}\text { In Qs. Al- } \\
\text { Qașaș [28]: } \\
\text { 88, Allah } \\
\text { said; “Do not } \\
\text { let them } \\
\text { turn you } \\
\text { away from } \\
\text { the } \\
\text { revelations } \\
\text { of Allah after } \\
\text { they have } \\
\text { been sent }\end{array}$ \\
\hline
\end{tabular}

${ }^{53}$ Makarem Shirazi, Tafsir Al Amtsal Fi Tafsir Kitabillah Al-Manzil, vol. 18, page. 473 


\begin{tabular}{|c|c|c|c|c|c|}
\hline & & & & $\begin{array}{l}\text { without } \\
\text { extinction }\end{array}$ & $\begin{array}{l}\text { down to you. } \\
\text { Rather, } \\
\text { invite 'all' to } \\
\text { 'the Way of' } \\
\text { your Lord, } \\
\text { and never be } \\
\text { one of the } \\
\text { polytheists." } \\
\text { [QS. Al- } \\
\text { Qașaș } \\
\text { [28]:87 }\end{array}$ \\
\hline$Z$ & استنَوَى & $\begin{array}{l}\text { Qs. Țāha } \\
\text { [20]:5 }\end{array}$ & $\begin{array}{l}\text { Thabathabai } \\
\text { explains the } \\
\text { outer } \\
\text { (zahir) } \\
\text { meaning of } \\
\text { word Istiwa } \\
\text { in kinayah } \\
\text { form that } \\
\text { means } \\
\text { kingdom. } \\
\text { Whereas } \\
\text { the inner } \\
\text { (batin) } \\
\text { meaning, } \\
\text { that } \\
\text { Thabathabai } \\
\text { interpret } \\
\text { the } \\
\text { sentence } \\
\text { "Istiwa 'alä } \\
\text { al-arsy" } \\
\text { means } \\
\text { discussion } \\
\text { about } \\
\text { tawhid }\end{array}$ & $\begin{array}{l}\text { This verse } \\
\text { shows His } \\
\text { universal } \\
\text { power. Allah } \\
\text { encompasses } \\
\text { everything } \\
\text { and ordained } \\
\text { everything in } \\
\text { the heaven } \\
\text { and earth } \\
\text { based on His } \\
\text { beauty and } \\
\text { His interests. }\end{array}$ & $\begin{array}{l}\text { Thabathabai } \\
\text { mention that } \\
\text { the word } \\
\text { istiwa in } \\
\text { Alquran } \\
\text { related to } \\
\text { tauhid } \\
\text { rubbubiyah } \\
\text { (God the } \\
\text { One who } \\
\text { preserved } \\
\text { everything). } \\
\text { The word } \\
\text { istiwa also } \\
\text { explain by } \\
\text { the sentence } \\
\text { "Istiwa 'alä } \\
\text { al-arsy" } \\
\text { repeatedly } \\
\text { in } 4 \\
\text { different } \\
\text { verses, } \\
\text { among } \\
\text { others Qs. } \\
\text { Al-A'raf:54, } \\
\text { Qs. Yunus:3, }\end{array}$ \\
\hline
\end{tabular}




\begin{tabular}{|c|c|c|c|c|c|}
\hline & & & rubbubiyah & & $\begin{array}{l}\text { Qs. Al- } \\
\text { Sajdah:4, Qs. } \\
\text { Al-Hadid:4. }\end{array}$ \\
\hline 3 & يَدْ & $\begin{array}{l}\text { Qs. Al- } \\
\text { Fath } \\
\text { [48]:10 }\end{array}$ & $\begin{array}{l}\text { This verse } \\
\text { means } \\
\text { isti'arah } \\
\text { khayaliyah } \\
\text { and } \\
\text { kinayah, } \\
\text { which } \\
\text { intend to } \\
\text { convince a } \\
\text { promise and } \\
\text { vow of the } \\
\text { Muslim to } \\
\text { Rasulullah } \\
\text { PBUH is the } \\
\text { same thing } \\
\text { as make a } \\
\text { promise to } \\
\text { God } \\
\text { Almighty, } \\
\text { there's no } \\
\text { other. Truly, } \\
\text { God } \\
\text { Almighty } \\
\text { agree with } \\
\text { human } \\
\text { promises. }\end{array}$ & Baiat Ridwan & $\begin{array}{l}\text { Qs. Al-Fath } \\
\text { [48]:10 has } \\
\text { the meaning } \\
\text { which in } \\
\text { accordance } \\
\text { with Qs. Al- } \\
\text { Nisa [4]:80, } \\
\text { "whose ever } \\
\text { obey the } \\
\text { prophet, } \\
\text { truly he has } \\
\text { obey God ". } \\
\text { According to } \\
\text { Țabātabā'i, } \\
\text { Qs. Al-Fath } \\
\text { [48]:10 and } \\
\text { Qs. Al-Nisa } \\
\text { [4]:80 is a } \\
\text { compliment } \\
\text { for wisdom } \\
\text { and } \\
\text { obedience of } \\
\text { the Prophet } \\
\text { PBUH to } \\
\text { God. }\end{array}$ \\
\hline
\end{tabular}

\section{Conclusion}

Based on the explanation above, it can be known that the interpretation of anthropomorphic verses in Muhammad Husain Thabathabai's interpretation was not ignoring any textual and spiritual aspects. According to Muhammad Husain Thabathabai, a textual understanding is the first knowledge for human being to discuss the inner 
meaning of al-Qur'an, so that if someone doesn't have any textual knowledge so it is impossible to disclose the inner meaning of a verse. Muhammad Husain Thabathabai interpreting three words in the anthropomorphic verses, such as wajh, yad, and istiwa. Textually, wajh means substance which includes in Qs. Al- Qașas [28]:88. Whereas, the word yad in Qs. Al-Fath [48]:10 means referring to Prophet's promises as the same as promise to God. Whereas, the word istiwā in Qs. Tāha [20]:5 understood as God's empire.

Based on the textual meaning, Muhammad Husain Thabathabai do interpretation by understanding the word wajh in Qs. Al- Qașaș [28]:88 as God's existence which released from destruction, because $\mathrm{He}$ is the Most Living Being even all existents comes from Him. Whereas, the word yad in Qs. Al-Fath [48]:10, according to Muhammad Husain Thabathabai interpretation means as His wills and His helps which all encompasses all the living being in the world. The last, the word istiwā in Qs. Tāha [20]:5 in Muhammad Husain Thabathabai takwil understood as His Greatness and Holiness in arranging, organizing and maintaining the whole system in the whole universe so that without His existence, everything will experience destruction within its system.

From the interpretation of the three words above, it can be known that God's existence is beyond space and time that describes His existence is out of destruction. It is different with human physical body which depends on space and time, which indicates destruction. On the one side, it is known that human existence needs God's existence to be exists in the world, and human needs His helps. From these two indications it can be known that God in the takwil of Muhammad Husain Thabathabai is the Most Holy and Greatest substance. His Greatness can be describes through the dependencies of beings and His Holiness can be describes through His releases of all physical existences which view as existentially low. Muhammad Husain Thabathabai has describe the essence of God's existence is different with beings. Besides, it is understood that the takwil of Muhammad Husain Thabathabai viewed as new point of view in understanding and interpreting the anthropomorphic verse as solution for the failures and mistakes done by the mufasirs (interpreters). 


\section{References}

Ali, Mohammad. Memahami Riset. Jakarta: Pustaka Cendikia Utama, 2011.

Ansori. Ulumul Qur'an: Kaiah-Kaidah Memahami Firman Tuhan. Jakarta: PT Raja Grafindo Persada, 2013.

Awang, Ramli dan Roslan Abdul-Rahim. "Antropomorfisme dalam Teologi Islam",Global Journal Al-Thaqafah, Desember 2017.https://www.researchgate.net/publication/32375158 6_Antropomorfisme_Dalam_Teologi_Islam

Arroisi, Jarman. "Integrasi Tauhid dan Akhlak dalam Pandangan Fakhruddin Ar-Razi”. Jurnal Tsaqafah, November 2013.

https://scholar.google.com/sholar?cluster=1607379589677085115\&hl $=$ en\&as_sdt $=0,5 \&$ sciod $\mathrm{t}=0,5$

Atabik, Ahmad. "Corak Tafsir Aqidah (Kajian Komparatif Penafsiran AyatAyat Aqidah)". Jurnal Esensia, October 2016.

https://scholar.google.com/scholar?cluster $=17959168827158207$ $7327 \& \mathrm{hl}=$ en\&as $s \mathrm{dt}=0,5 \&$ sciodt $=0,5$

Budiman, Ikhlas. "Penerapan Teori-teori Filosofi dalam penafsiran alQur’an”. Jurnal Tanzil, 2015.

https://scholar.google.com/scholar?q=ikhlas+budiman+penerapa

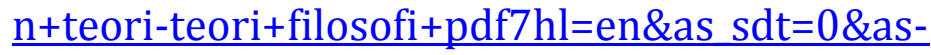
vis $=1 \&$ oi $=$ scholart

Departemen Agama RI. Al-Qur'an dan Terjemahannya. J-ART: Bandung, 2004.

Fauzan, Ahmad. "Manhaj Tafsir al-Mizan fi Tafsir al-Qur'an Karya Muhammad Husain Tabataba'i". Jurnal Ilmu Alquran dan Tafsir: AlTadabbur, October 2018.

https://scholar.google.com/scholar?cluster $=94041510068446564$ $21 \& \mathrm{hl}=$ en\&as_sdt $=0,5 \&$ sciodt $=0,5 \# \mathrm{~d}=$ gs_qabs $\& u=\% 23 \mathrm{p} \% 3 \mathrm{D}$ ¿Zsb8YNBgolI

Firmanuloh, Ahmad, Badrudin. Metode Penafsiran Ayat-Ayat 
Mutasyabihat dan Implikasinya: Studi Komparasi Tafsir azZamakhsyari, ar-Razi, dan Ibn Taimiyah. Thesis. Jakarta: IIQ, 2018. Gusmian, Islah. Khazanah Tafsir Indonesia: Dari Hermeneutik Hingga Ideologi. Jakarta: Teraju, 2013.

Hady, Aminullah, El. Ibn Rusyd Membela Tuhan: Filsafat ketuhanan ibn Rusyd. Surabaya: LPAM, 2004.

Halim, Muhammad, Abdul. Menafsirkan Al-Qur'an Dengan Metode Menafsirkan Al-Qur'an Dengan Al-Qur'an. Bandung: Marja, 2012.

Haq, Sansan, Ziaul. "Hermeneutika Sufistik: Telaah Epistemologi Takwil Ibn Arabi”. Jurnal At-Tibyan, July 2019.

https://www.journal.iainlagsa.ac.id/index.php/tibyan/article/vie $\underline{\mathrm{w} / 890}$

Husti, Ilyas. "Studi Kritis Pemikiran Quraish Shihab Terhadap Tafsir Muhammad Husain Ṭabāțabā'i”. Jurnal Al-Fikra, January-July 2015. https://scholar.google.com/scholar?cluster $=928221385003$ $2543049 \& \mathrm{hl}=$ en\&as $\mathrm{sdt}=0,5 \&$ sciodt $=0,5 \# \mathrm{~d}=$ gs qabs $\& \mathrm{u}=23$ \%p\%3DSZVmPFEM0YAI

Kaelan. Metode Penelitian Agama Kualitatif Interdisipliner. Yogjakarta: Paradigma, 2010.

Katsir, Ibnu. Tafsir Ibnu Katsir. Kairo: Imam Syafi'i Literature. 2011.

Kerwanto. Metode Tafsir Esoeklektik. Bandung:Mizan, 2018.

-. "Penafsiran Bāthini (Esoteris) Thabāthabā'i dalam Tafsir alMīzān”. Jurnal Tanzil, 2016.

https://onesearch.id/Record/IOS2836.articel-191

Khairudin,Fiddian. "Makna Imam Menurut Al-Thabathaba'i dalam Kitab Al-Mizan fi Tafsir Al-Qur'an". Jurnal Syahadah, April 2016.

https://scholar.google.com/scholar?cluster $=22104398214849290$ $47 \& \mathrm{hl}=$ en\&as $\mathrm{sdt}=0,5 \&$ sciodt $=0,5 \# \mathrm{~d}=$ gs $q$ abs $\& \mathrm{u}=\% 23 \mathrm{p} \% 3 \mathrm{D}$ F7D8ZE4PrR4I 
Khasinah, Siti. "Hakikat Manusia Menurut Pandangan Islam dan Barat". Jurnal Ilmiah Didaktika, February 2013.

https://scholar.google.com/scholar?cluster $=11355380530094492$

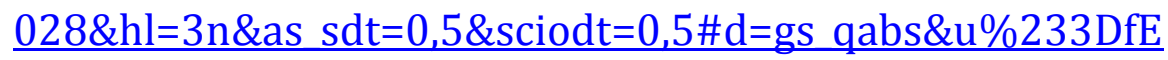
mrwW1qlp0I

Lestari, Ayu, Fitri. Metode Pendidikan Islam (Kajian Tafsir Tematik). Essay, Lampung: State Islamic University Raden Intan.

Maliki, "Tafsir Ibn Katsir: Metode dan Bentuk Penafsirannya”. Jurnal elUmdah: Ilmu Al-Qur'an dan Tafsir, January-Juny 2018.

https://journal.uinmataram.ac.id/index.php/elumdah/article/view/410

Maznur, Imam, Al-Allamah, Ibn. Lisan al-'Arab. Mesir: Dar al-Hadits, 1423 $\mathrm{H}$.

Nasr, Seyyed, Hossein. Al-Hikmah Al-Muta'aliyah Mullā Șadrā: Sebuah Terobosan dalam Filsafat Islam. Penj Mustamin al-Mandary. Jakarta: Sadra Press, 2017.

Otta, Yusno, Abdullah. "Dimensi-Dimensi Mistik Tafsir Al-Mizan: Studi atas Pemikiran Thabathaba'i dalam Tafsir Al-Mizan". Jurnal Potret Pemikiran,July-December 2015.

https://scholar.google.com/scholae?cluster $=108840469233$ 36559091\&?hl=en\&as_sdt=2005\&sciodt $=0,5 \# d t=g s \_q a b s \& u$ $=\% 23 \mathrm{p} \% 3 \mathrm{D} 86 \mathrm{kouALnC5 \textrm {cI }}$

Qāsim, Al-Khawārizmī, Al-. Al- Kasyaf 'An Haqāiq Al-Tanzil Wa'uyūn AlAqāwil Fi Wujūh Al-Ta'wil. T.tp: Dar al-Fikr, t.t.

Ritonga, Abdul, Hamid. "Hadis-Hadis Antropomorfisme: Analisis terhadap Takwil Ibn Hajar Al-'Asqalani Dalam Fath Al Bari”. Jurnal MIQOT, July-December 2013.

https://jurnalmiqotojs.uinsu.ac.id/index.php/jurnalmiqot/article/ view $/ 82$

Saleh. Analisis Ayat-Ayat Mutasyabih Menurut Zamakhasyari dalam Tafsir 
Al-Kasysyaf. Skripsi. Riau: State Islamic University Sultan Syarif Kasim, 2011.

Semiawan, Conny R. Metode Penelitian Kualitatif. Jakarta: PT. Grasindo, 2010.

Shirazi, Naser, Makarem. Tafsir Al-Amthal:Terjemah. Jakarta:Sadra Press, 2015.

-Tafsir Al-Amthal Fī Tafsir Kitabillah Al-Manzil. Qom: Madrasah Imam Ali bin Abi Thalib, $1461 \mathrm{H}$.

Supriadi, " Al-Asy'ariyah (Sejarah, Abu al-Hasan al-Asy'ari, dan DoktrinDoktrinTeologinya)”. Jurnal Sulesana, 2014.

https://scholar.google.com/scholar?cluster $=60531498213088958$ $18 \& \mathrm{hl}=$ en\&as $\mathrm{sdt}=0,5 \& \mathrm{sciodt}=0,5 \# \mathrm{~d}=$ gs $\_$abs $\& \mathrm{u}=\% 23 \mathrm{p} \% 3 \mathrm{D}$ SgJWB7EbAVQI

Syahrastani, Al-. Al-Milal wa Al-Nihal: Aliran-Aliran Teologi dalam Islam. Bandung: Mizan Pustaka, 2004.

Syukur, Abdul. "Mengenal Corak Tafsir Al-Qur'an", Jurnal El-FURQONIA, August, 2015.

https://scholar.google.com/scholar?cluster $=17769822122091429$

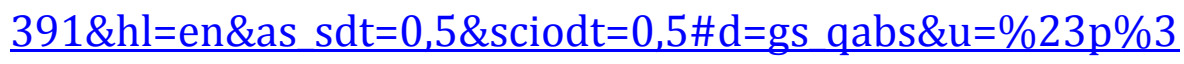
DDz4jTRIXm_YI

Thabathabai, Muhammad, Husain. Al-Mĩzan fi Tafsīr Al-Qur'ān. Qum: Hauzah Alamiyah, 1417 M.

Yunus, Mahmud. Tafsir Qur'an Karim. Jakarta:Mahmud Yunus Wa Dzurriyah, 2011.

Yusuf, M. Yunan. Alam Pikiran Islam Pemikiran Kalam: Dari Khawarij Ke Buya Hamka Hingga Hasan Hanafi. Jakarta: Pranada Media, 2014.

Yusufian, Hasan. Kalam Jadid: Pendekatan Baru dalam Isu-Isu Agama. Jakarta: Sadra Press, 2014. 